\title{
Exploring the function of relative sentences in New Testament Greek
}

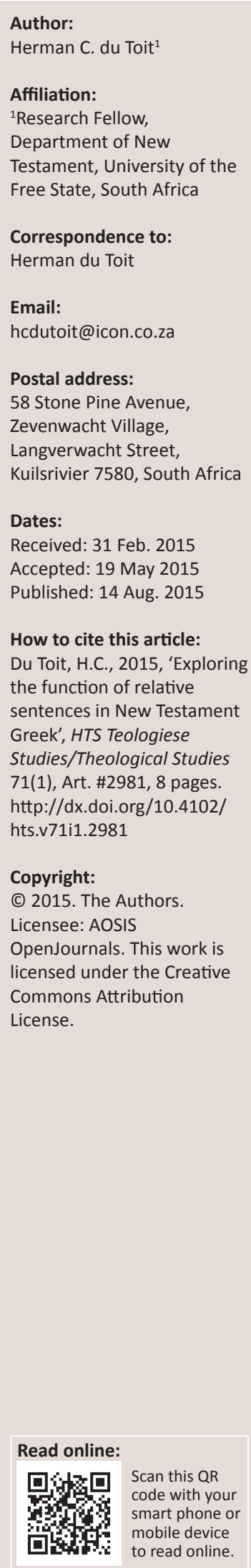

The traditional view of the function of relative sentences in the Greek New Testament differed markedly from that in many modern languages. This view was challenged in the mid-1980s and a number of striking correspondences with a variety of modern (and some classical) languages were pointed out, despite some differences. The purpose of this article is, amongst others, to explore functional aspects of the relative sentence against this background, and to provide further substantiation for the new view and some new perspectives in the light of recent literature. The conclusion is that the view of the functions of the relative sentence, as developed in the mid-1980s, still seems valid. The view is also supported to a large extent by recent literature, especially with respect to the relative sentence's adjectival use, despite differences relating to nuances and terminology. However, recent New Testament grammars still distinguish so-called 'conditional', 'concessive', 'causal', 'final' and 'resultative' relative sentences as part of their adverbial use, despite strong evidence to the contrary. The conclusion reached is that relative sentences seem to have the following functions in New Testament Greek, which correspond to their functions in numerous modern languages: (1) Identifying a referent(s) with or without an overt nominal antecedent. (2) Providing background or additional information for a nominal or sentential antecedent in the form of a parenthesis, explanation or concession, or some combination of these. (3) Qualifying a verb with regard to time, location or manner. (4) Functioning as a conjoined sentence.

\section{Introduction}

The relative construction, which commonly consists of an antecedent and a relative sentence, is a pervasive phenomenon in the languages of the world, but occurs in a variety of syntactic forms. In view of this, Comrie (1989:142) argues that a functional (semantic, cognitive) definition should be given of the relative construction (in his terms, 'relative clause') which is independent of language-specific syntax. Assuming that restrictive relative sentences are more central to the notion of the relative construction than are non-restrictives, he defines the relative construction as consisting necessarily of a head and a restricting clause (Comrie 1989:143). Whereas the head has a potential range of referents, the restricting clause 'restricts this set by giving a proposition that must be true of the actual referents of the overall construction.' Compare his example, which is repeated here as $(1):^{1}$

\section{(1) I ate [the potato [that Hasan gave to Sinan]].}

In (1), the head 'potato' has a range of potential referents, which is limited to one potato by the relative sentence, of which the proposition 'Hasan gave the potato to Sinan' is true (Comrie 1989:142). It should be noted that Comrie's definition includes not only relative constructions that contain finite relative sentences, but also non-finite (e.g. participial) constructions, such as 'leaving on Flight 738' in the sentence 'Passengers leaving on Flight 738 should proceed to the departure lounge.' It includes also restrictive attributive adjectives like 'good' in the sentence 'The good students all passed the examination' (Comrie 1989:143-144).

The relative construction is also an important feature of Hellenistic (and Classical) Greek, exhibiting a variety of functional, syntactic and stylistic features. It was pointed out by Robertson (1919:954) already that relative sentences introduced by the relative pronoun, apart from the adverbial uses, are the most frequent subordinate sentences in the Greek New Testament (NT), and probably almost equal in some authors to all the other classes together. It is also regarded by Robertson (1919:954) as the chief means of periodic structure in the NT (cf. his example from

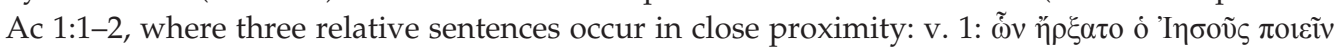

1.To simplify the discussion and for ease of reference, the following conventions are followed in the numbered examples in this article: relative constructions are indicated by italicized $(=[])$ brackets and relative sentences by square (= [ ]) brackets. 


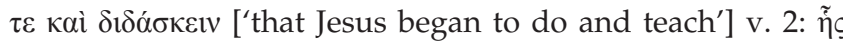

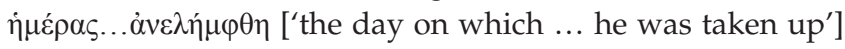

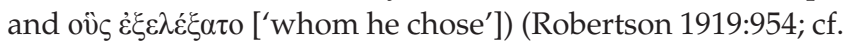
also Robertson's other examples: 1 Cor 15:1-2 and Rm 9:4f.)

A survey of the literature indicates that the traditional description of the function of the relative sentence in the Greek NT used to differ markedly from that in modern languages. In the mid-1980s, however, the traditional view was challenged by the author (Du Toit 1984, 1986), who pointed out a number of striking correspondences between the function of the relative sentence in NT (and Classical) Greek and in a variety of modern languages. The purpose of this article is, amongst others, to explore functional aspects of the relative sentence against this background, and to provide further substantiation for the new view and also new perspectives in the light of recent literature. In this regard it makes use, amongst others, of material on relevant literature after the mid-1980s which was presented by the author in an unpublished paper at the Meeting of the Studiorum Novi Testamenti Societas (SNTS) in 2014 (Du Toit 2014). The article aims also to arrive at a comprehensive description of the main functions of the relative sentence in NT Greek in the light of the above.

\section{The function of relative sentences in some modern languages}

In many modern languages, the notion of 'restriction' has played an important role in describing the function of relative sentences. In English, for example, the distinction between 'restrictive' and 'non-restrictive' relative sentences has been recognised for decades already (cf. Chomsky 1977:65; Loetscher 1973:362-366; Smith 1964:248; etc.). Radford (2009) gives the following example of a restrictive relative sentence (in his terms, 'relative clause'):

(2) I saw the [man [who/that they arrested]] on TV. (p. 226)

According to Radford (2009:226), the function of the relative sentence in (2) is to restrict the class of men referred to in the sentence to the one whom they arrested. Radford (2009:226) distinguishes also a second type of relative sentence, namely, appositive relative sentences, a term which is often used synonymously with 'non-restrictive' (also 'descriptive' and 'explanatory') for this type of relative sentence (cf. Comrie 1989:138; Lehmann 1984:270-280; Quirk et al. 1985:12391244; etc.). Compare his examples, which are repeated here as $(3 a-c)$ :

(3)a. [John [(who used to live in Cambridge)]] is a very good friend of mine.

b. Yesterday I met [my bank manager, [who was in a filthy mood]].

c. [Mary has left home - [which is very upsetting for her parents]].

According to Radford (2009:226), appositive relative sentences in English generally serve as parenthetical comments or afterthoughts which are set off in a separate intonation group from the rest of the sentence in the spoken language. This corresponds to a remark by Lehmann (1984:263) that appositive relative sentences in languages generally have an 'Intonationsbruch' ['breach in intonation'] between the post-nominal relative sentence and the antecedent-noun, whereas in restrictive relative sentences the intonation is continuous at this point.

Appositive relative sentences in English are indicated by parentheses, a comma or a hyphen in the written language (see examples [3a-c] above) (Radford 2009:226). In German, the writing convention is followed to use a comma after the antecedent in appositive as well as restrictive relative sentences (Lehmann 1984:47).

The notion of 'restriction' has also been used successfully in describing the function of relative sentences in a variety of other modern (as well as ancient) languages. An example from older literature is the compilation by Peranteau, Levi and Phares (1972) of papers delivered at the Relative Clause Festival of the same year, where the notion of 'restriction' is applied also in languages as divergent as Czech and Ukrainian (Golạb 1972:30-39), Latin (Ehrenkranz \& Hirchland 1972:23-29), French (Perlmutter 1972:73-105), Finnish (Karlsson 1972:106-114), Basque (De Rijk 1972:115-135), Georgian (Aronson 1972:136-143), Arabic (Kilean 1972:144-152), Malagasy (Keenan 1972:169189), Japanese (McCawley 1972:205-214) and Korean (Tagashira 1972:215-229).

More recently, 'restriction' has also been used in describing the function of relative in sentences in the following languages: Dagbani, Crow and Lakhota (Lehmann 1984:262268); Persian and Turkish (Comrie 1989:139, 142-143); and Dutch, Korean, Abkhaz, Basque, Lahu and Nama (De Vries 2006:234-235, 264).

\section{The function of relative sentences in New Testament Greek Introduction}

The discussion below focuses on instances where relative sentences are introduced by the relative pronouns ö $\varsigma$

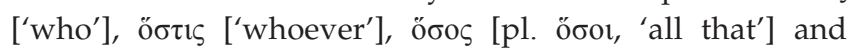
ómoĩos ['what sort of']. The meanings of the definite ö $\varsigma$ ['who'] and indefinite ö $\sigma \iota \varsigma$ ['whoever'] are no longer clearly distinguished in the NT, and vary also between authors such as Matthew, Luke and Paul (cf. Blass \& Debrunner

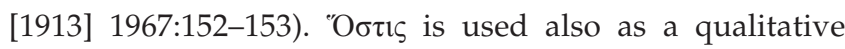
relative pronoun, for example, Matthew 7:15a: $\pi \rho 0 \sigma \varepsilon ́ \chi \varepsilon \tau \varepsilon \dot{\alpha} \pi$ ò

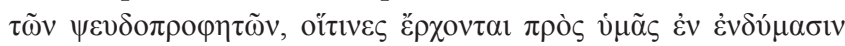
$\pi \rho \beta \beta \alpha \dot{\tau} \omega v$ ['beware of false prophets, the very ones who come to you in sheep's clothing'] (Wallace 1996:344). The status of ó $\pi$ oĩo $\varsigma$ as a relative pronoun is uncertain. Danker (2000:717)

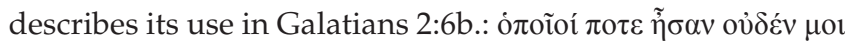
$\delta 1 \alpha \varphi \varepsilon_{\rho} \rho 1$ ['whatever they were makes no difference to me'] as 'almost equal to a relative'. 


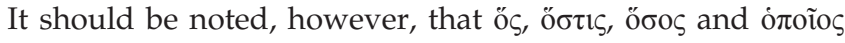
have other uses in the NT, in addition to their use as relative pronouns:

1. "O $\varsigma$, for example, can serve also as a demonstrative or

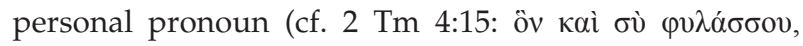

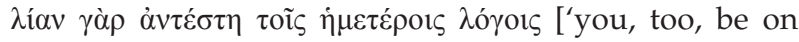
your guard against him, for he strongly opposed our message']). Blass and Debrunner ([1913] 1967:154) describe this use of ö $̧$ as 'a kind of "relative connection" that is particularly Latin, but also Greek' (cf. also Boyer 1988:235-236; McKay 1994:68; etc.). This use of ö occurs also in classical Greek, for example, in Xenophon's

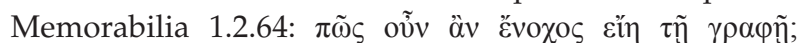

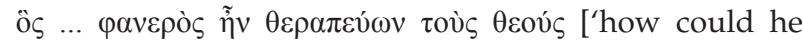
then be subject to the indictment? For he ... is known to have worshipped the gods'] (Smyth 1976:560). "O $\varsigma$ is sometimes used for $\tau$ í after verbs of 'knowing' (cf. Lk

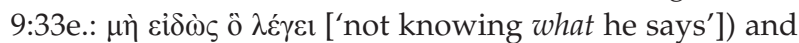

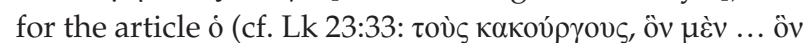
$\delta \varepsilon \dot{~[' t h e ~ c r i m i n a l s, ~ t h e ~ o n e ~ . . . ~ t h e ~ o t h e r '], ~ h e r e ~ u s e d ~ i n s t e a d ~}$

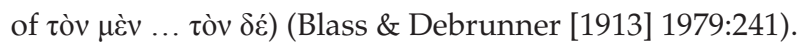
The use of ö $\varsigma$ in direct questions, perhaps in Matthew

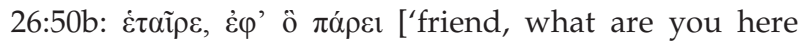
for?'], is controversial. (see also Boyer 1988:252-253)

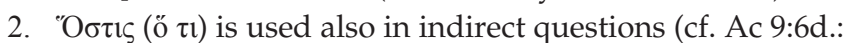

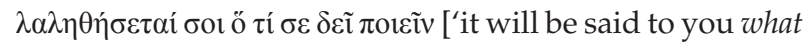
you should do']), as in Classical Greek (cf. Xenophon's

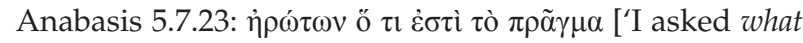
the matter was']) (Smyth 1976:601). The use of ö $\tau 1$ in

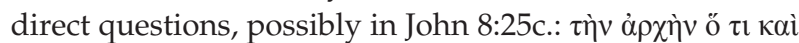
$\lambda \alpha \lambda \tilde{\omega}$ i $\mu i \tilde{i}$; ['What have I been telling you all along?'], is also controversial (cf. Blass \& Debrunner [1913] 1967:157).

3. "Oбos, which occurs in the NT only in the nominative and accusative case (except in Hebrews), is used also in

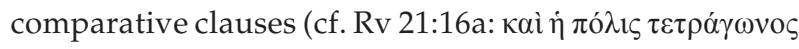

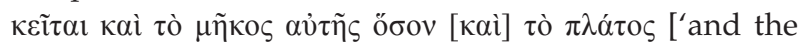
city is laid out as a square, and its length is as great as

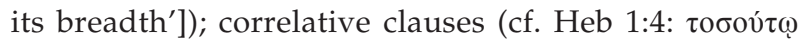

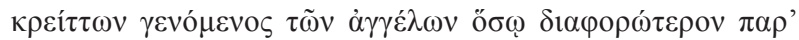

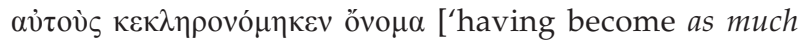
superior to the angels as he has inherited a better name than them']); and in expressions such as ö $\sigma o v$

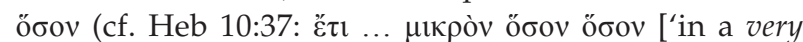
little while']).

4. O $\pi$ oĩo is used also as a correlative pronoun in combination

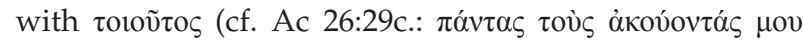

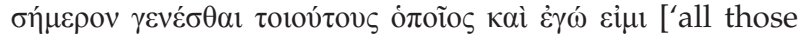
listening to me today become such as I am']).

For further discussion and examples of uses of ö $\zeta$, ő $\tau \tau 1 \zeta$, ö $\sigma o \varsigma$ and $\dot{\pi} \pi \circ \tilde{o}_{\mathrm{o}}$, where they do not introduce relative sentences, see Du Toit (1984:74-76, 86-89 [fnn. 17-21]).

Although the focus in this article is on relative sentences introduced by the above relative pronouns, instances are also briefly discussed where relative sentences are introduced by relative adverbs, such as ö $\pi$ ov ['where'], oṽ ['where'], ö $\theta \varepsilon v$ ['from where'] and ö $\tau \varepsilon[$ ['when'], and occasionally by $\tau$ '́ $\varsigma$ ['who' or 'what']. The relative adverbs oil ['where to'], हैv $\theta \alpha$ ['where'], ö $\pi$ o ['wherever to'] and ó $\pi$ ó $\theta \varepsilon v$ ['wherever from'] do not appear in the NT as in Classical Greek.

\section{Restrictive relative sentences}

In older literature on the Greek NT, functional aspects of the relative sentence are not commonly discussed in terms of restriction, as in the case of modern languages (see above). Terms such as 'substantival', 'adjectival', 'cause', 'adverbial' 'concession', 'result', 'purpose' et cetera, are used instead. The notion of 'restriction' is also absent from the standard NT reference grammars of Blass and Debrunner ([1913] 1967, [1913] 1979).

In the few cases where 'restriction' is used in older literature, it normally plays a relatively minor role in the overall description of the relative sentence. For example, Burton (1894:119) states that 'all relative clauses whether adjective or adverbial may be distinguished as either restrictive (my italics) or explanatory.' A restrictive relative sentence 'defines its antecedent, indicating what person, thing, place or manner is signified', whereas an explanatory relative sentence 'adds a description to what is already known or has been defined adequately. The former identifies, the latter describes.' It should be noted that although Burton uses the term 'restrictive' for this type of relative sentence, his description is partly in terms of 'identification'. Burton (1894:119) gives the following example of a restrictive relative sentence:

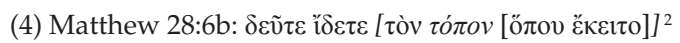

['come, see the place where he lay']

However, the distinction between restrictive and explanatory relative sentences is not used in the major part of his discussion (Burton 1894:117-129). Instead, the following categories are used: (1) Definite relative clauses, excluding those which express purpose, and those introduced by words meaning 'until'; (2) Indefinite or conditional relative clauses, excluding those which express purpose, and those introduced by words meaning 'until'; (3) Relative clauses expressing purpose; and (4) Relative clauses introduced by words meaning 'until'.

Another instance of the use of 'restriction' in older literature, albeit in slightly different terms, occurs in Dana and Mantey (1957:272), who state (under the heading 'Adjectival Clauses') that a relative sentence (in their terminology, 'relative clause') is sometimes used 'to directly limit (my italics) or define a substantive, performing a pure adjective function.' In (5)

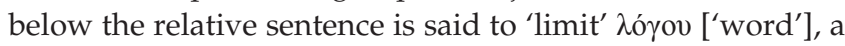
notion that is synonymous with 'restricts':

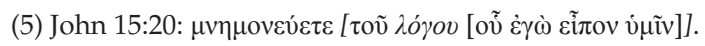

['remember the word that I said to you']

2.In numbered Greek examples, such as this one, the core of the relative construction (usually a noun, but sometimes quantifiers, demonstrative pronouns, etc.), which (usually a noun, but sometimes quantifiers, demonstrative pronouns, etc.), which
usually determines the number and gender of the relative pronoun, is indicated usually de
by italics. 
Dana and Mantey (1957:224-225) also point out that the Greek articular modifying participle could also be used restrictively (or non-restrictively).

In more recent literature, the use of 'restriction' is more common. Young (1994:231), for example, refers to restrictive relative sentences (in his terminology, 'relative clauses'), but defines them as identifying a head noun (see Du Toit 2014:9 for further information).

The grammar of Wallace (1996:660-662), which distinguishes substantival, adjectival and adverbial clauses as part of the syntactical function of dependent clauses, uses 'restriction' as one of the terms to define the function of adjectival clauses. According to Wallace (1996:662, 336), some adjectival clauses (to which a group of relative clauses belongs) restrict a noun, pronoun, or other substantive. Unfortunately, Wallace does not indicate which of his examples are instances where the relative sentence restricts the substantive, in contrast to 'describing' or 'explaining' it (see Du Toit 2014:9 for examples).

Voelz (2006:401-403) (referred to briefly by Du Toit 2014:9), broadens the application of the notion of 'restriction' to include also attributive participles. He points out, for example, that the attributive participial phrase

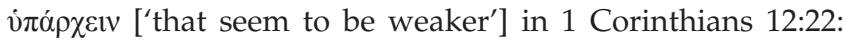

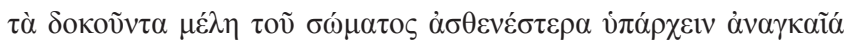
$\dot{\varepsilon} \sigma \tau \iota$ ['the members of the body that seem to be weaker are

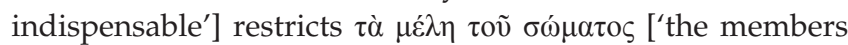
of the body'] to a subcategory of all members of the body, some of which are not weaker. This is parallel to Comrie's (1989:143-144) example of the attributive phrase 'leaving on Flight 738 ' in the English sentence 'Passengers leaving on Flight 738 should proceed to the departure lounge' quoted above.

However, Voelz's (2006:402) statement that 'subordinate clauses headed by a relative pronoun are non-restrictive in their meaning' does not seem to be correct. Although the relative sentences in his examples (1 Pt 2:11, Lk 2:4; Ac 1:1011a.; etc.), all of which are introduced by relative pronouns, are non-restrictive, this does not hold true of all such relative sentences. Evidence seems to show that there are, in fact, many examples in the NT where the relative sentence is restrictive in such cases (cf. for example, [4] and [5] above).

Porter (2013:82-98) (referred to briefly by Du Toit 2014:9) examines recent commentaries and translations of 1 Thessalonians 2:14-15 with regard to the question whether the coordinate attributive participial clauses in verse 15: $\tau \tilde{\omega} v$

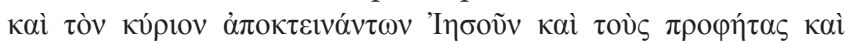

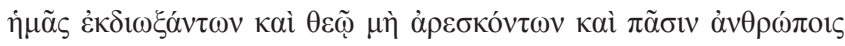
$\dot{\varepsilon} v \alpha v \tau i ́ \omega v$ ['who killed both the Lord Jesus and the prophets and drove us out and do not please God and are hostile to all people'] are restrictive or non-restrictive with respect to

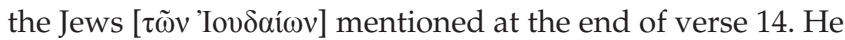
argues for regarding them as 'restrictive', despite the comma in the Greek text at the end of verse 14, which is taken by almost all English translations before 1989 as an indication of a non-restrictive clause (cf., for example, the translation of the Revised Standard Version [RSV] of the last part of $\mathrm{v}$. 14 and v. 15: v. 14: 'you suffered the same things from your own countrymen as they did from the Jews, v. 15 who killed both the Lord Jesus and the prophets, and drove us out, and displease God and oppose all men') (cf. also Gilliard 1989:482, 488, 490f.).

Porter's arguments are not discussed in any detail here. The issue illustrates, however, one of the challenges involved in the interpretation of ancient written texts, where phonological data is not available as is the case in modern languages. Furthermore, punctuation was variable and not fixed in early Greek manuscripts, with relatively fixed punctuation not occurring until well after development of the codex. Secondly, there are no manuscripts of this portion of 1 Thessalonians that predate the major codexes (Porter 2013:85).

Du Toit (1984:56-73, 1986:6-16) applies the notion of 'restriction', as used in the literature on modern languages, to relative sentences in the NT and points out its usefulness in the light of the many correspondences between Greek and modern languages in this regard. He argues, however, for a modification in the use of the term and proposes the use of 'identification' instead. This view was influenced by the work of Ebert (1973:5) on English, who argues that, viewed within a speech-act model, restriction was only typical of a specific subgroup of relative sentences that are normally classified as 'restrictive', namely, relative sentences describing 'types', and that their real function was that of identification. Identification could, however, take place by means of restriction, amongst others. Compare her example given in (6):

(6) Fred knows [a girl [who has been to the Relative Clause Festival]]. (Ebert 1973:6)

In (6) the relative sentence does not restrict the class of unspecified girls as such, but rather identifies who the girl is (for a more detailed discussion of Ebert's ideas, see Du Toit [1984:51-52, 1986:4]).

The argument by Du Toit $(1984,1986)$ still seems to be valid. Compare the sentence in (7):

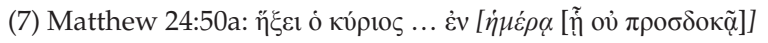

['the master will come ... on a day when he does not expect him'] (pp. 56-73, 6-16)

Here the relative sentence does not seem to restrict the reference of the antecedent $\eta \mu \varepsilon \varepsilon^{\alpha}\left[{ }^{\prime}\right.$ day'] $^{\prime}$, but rather identifies

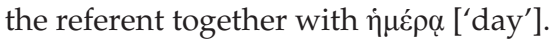

'Identification' seems to work well also in the case of free relatives, where there is no overt antecedent whose reference can be 'restricted'. Free relatives are usually discussed in literature on the NT as part of the 'substantival' use of the relative sentence (cf. Wallace 1996:660-661: 


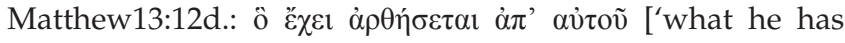
will be taken away from him'] or as 'nominal relative clauses' [cf. Boyer 1988:236]). Compare the following example:

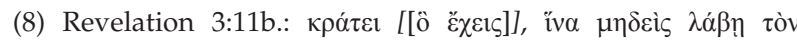

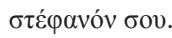

['hold on to what you have, so that no one can take your crown']

In (8), the free relative ô é $\chi \varepsilon 1 \varsigma$ ['what you have'], which is here

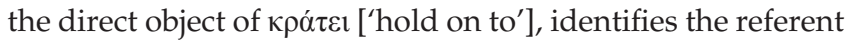
that is spoken of on its own. Likewise relative sentences with an overt antecedent that are introduced by relative adverbs, for example, by ö $\tau \varepsilon$ ['when'], oũ ['where'], and ö $\theta \varepsilon v$ ['from where'], could be regarded as 'identifying', as in the following examples:

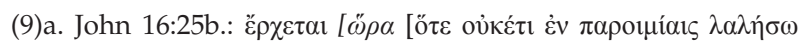
viñv]].

['a time is coming when I will no longer speak to you by means of figures of speech']

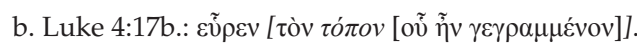

['he found the place where it was written']

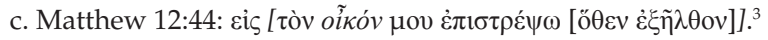

['I will return to my house from where I departed']

\section{Appositive relative sentences}

Since the term 'identifying' seems preferable in the case of relative sentences normally referred to as 'restrictive', the term 'appositive' will be used here for a function of relative sentences that is often referred to as 'non-restrictive' (cf. Porter 2013:86; Voelz 2006:401-403; etc.). The term 'appositive' seems appropriate in view of its inherent notion of 'apposition', and is often used in literature on modern languages (for example, Lehmann 1984:270-280; Radford 2009:226; etc.), although 'non-restrictive' is preferred by some scholars (for example, Chomsky 1977:65).

A few of the older Greek grammars, such as Burton (1894:119) and Dana and Mantey (1957:272), distinguish an appositive (in their terms, 'explanatory' and 'defining', respectively) function of adjectival relative sentences. According to Burton, an explanatory relative sentence, in contrast to a restrictive one, 'adds a description to what is already known or has been defined adequately', as in (10):

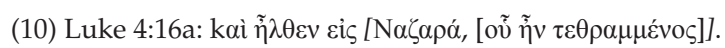

['he went to Nazareth, where he had been brought up']

Young (1994:231) defines appositive relative sentences (in his terms 'non-restrictive') as 'describing (my italics) a head noun.' Wallace $(1996: 662,336)$ includes also in his definition of relative sentences (as a sub-group of adjectival clauses) their use in 'describing' or 'explaining' a noun, pronoun, or other substantive. Unfortunately, Wallace does not indicate which of his examples are 'describing' or 'explaining' (cf. also Gilliard 1989:482, 488, 490f.; Voelz 2006:401-403; and Porter 2013:86, who all use 'nonrestrictive' for this type of relative sentence).

Some NT grammars refer to a function of the relative sentence, which could also be classified as 'appositive', namely, instances where the relative sentence is used in parenthetical expressions. However, this usually plays only a minor role in their description of relative sentences. Blass and Debrunner ([1913] 1967:243), for example, make brief mention of this use at the end of a general discussion on parenthesis (Blass \& Debrunner ([1913] 1967:242-243), which forms part of a section on sentence structure. Other uses of the relative sentence are discussed as part of the section on 'Moods' (Blass \& Debrunner ([1913] 1967:191-192). According to Blass and Debrunner (1913] 1967:243), parenthetical relative sentences occur in two situations in the NT, firstly, where the structure of the sentence is not interrupted, as in (11):

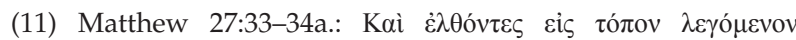

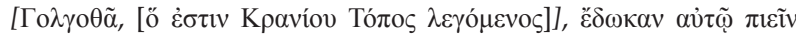
oĩvov $\mu \varepsilon \tau \grave{\alpha} \chi 0 \lambda \tilde{\eta} \varsigma \mu \varepsilon \mu 1 \gamma \mu \varepsilon \dot{v}$ ov.

['and when they came to a place called Golgotha, which means "Place of Skull", they gave him wine mixed with gall to drink']

The parenthetical nature of the relative sentence in (11) corresponds to the one in Radford's (2009:226) English example, which is quoted in (3a) above and repeated in (12):

(12) [John [(who used to live in Cambridge)]] is a very good friend of mine.

Secondly, a relative sentence could be inserted into direct discourse of which it does not form part, as in the example in (13):

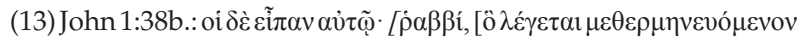

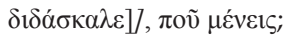

['and they said to him, "Rabbi" \{which translated means "Teacher"\}, where are you staying?'] (Blass \& Debrunner [1913] 1967:243)

A further perspective on appositive relative sentences is provided by Du Toit (1984:53-56, 77-78, 1986:4-5), whose view is influenced, amongst others, by the work of Loetscher (1973) on appositive (in his terminology, 'non-restrictive') relative sentences in English. Loetscher (1973:365) points out that relative sentences in discourse typically provide background information, and identifies the following ways in which this is done, namely, as (1) parentheses (which he defines as 'expressions which are typically inside another sentence, but are not intrinsically bound to it, i.e. there exists no causal or time-space relationship'), (2) explanations, and (3) concessive expressions (Loetscher 1973:361-362). His examples of the three uses are given in (14a, b and c), respectively:

(14)a. [The lark, [which builds its nest on the ground]], has a very sweet song. (Loetscher 1973:363).

b. [Sam, \{whom Jack had given a blow on the head\}], went down and started screaming. (Loetscher 1973:363)

c. [Chuck, \{who can't even write\}], was elected judge. (Loetscher 1973:362) 
Du Toit $(1984: 345,1986: 16)$ defines the function of appositive relative sentences in NT Greek also as providing background or additional information for an antecedent. This could be expressed in the form of a parenthesis, explanation, concession (or some combination of these), or as an afterthought. This definition seems valid in the examples of Blass and Debrunner ([1913] 1967:242-243), quoted in (11) and (13) above. In both cases the appositive relative sentence could be interpreted as giving background information for their antecedent in the form of an explanatory parenthesis.

The above examples of the relative sentence's appositive function refer to instances where the antecedent is a nominal expression. Appositive relative sentences can also have a sentence as antecedent, as in (15):

(15) Acts 2:32: [ $\tau$ oṽ $\dot{\varepsilon} \sigma \mu \varepsilon v \mu \alpha \dot{\rho} \rho \tau \rho \varepsilon \varsigma]]$.

['God raised this Jesus to life, which all of us are witnesses of']. (Du Toit 1984:297, 2014:11)

In (15) the relative pronoun oṽ could be interpreted as a sentential relative with the meaning 'of which' (as reflected in the translation), and the relative sentence as referring to

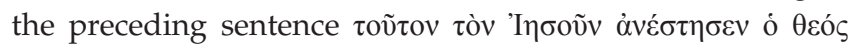
['God raised this Jesus to life'] as its antecedent, providing additional information on it. In this interpretation, the function of the relative sentence corresponds to that in the English example from Radford (2009), which is quoted in (3c) above and repeated in (16):

(16) [Mary has left home - [which is very upsetting for her parents]]. (p. 226)

The relative sentence in (15) could also be interpreted as an appositive relative sentence providing background

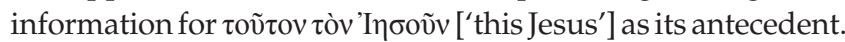
In this case the translation would be: 'God raised this Jesus to life, of whom all of us are witnesses.' However, the former interpretation seems preferable in the context (cf. also Winer [1855] 1882:479 on this verse). It is often difficult in practice to distinguish between different functions of the relative sentence in contexts that are not transparent in this regard.

In NT (and Classical) Greek and English only appositive sentences can have nominal elements as well as sentences as their antecedent. Identifying relative sentences, on the other hand, have only nominal elements as their antecedents.

\section{Adverbial and pseudo-adverbial relative sentences}

Relative sentences introduced by relative adverbs of time, place and manner occur often in the NT without an overt antecedent. In such cases, these free relatives function like an adverb and qualify a verb. Compare the examples in $(17 \mathrm{a} \& \mathrm{~b})$ :

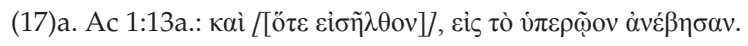

['and when they entered, they went up to the upstairs room']

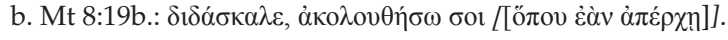

['Teacher, I will follow you wherever you go']

In $(17 \mathrm{a} \& \mathrm{~b})$, the relative sentences introduced by ö $\tau \varepsilon$ ['when'] and ö $\pi$ ov ['where'], denote time and place with regard to

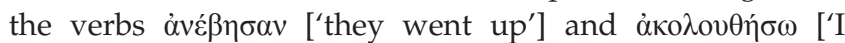
will follow'], respectively. The status of temporal sentences (such as the one in [17a]) as a type of relative sentence is supported by Blass and Debrunner ([1913] 1967:192), who regard temporal sentences in general as 'only a special class of relative clause that exhibit the same constructions' (so also Boyer 1988:238-240; Lehmann 1984:319-325; cf. Robertson 1919:953-954 for a different view).

Similar examples occur also in modern languages, for example, in English. Compare the examples in (18a \& b) with those in (17a \& b), respectively.

(18)a. John will depart [[when his car is ready]].

b. She travels with him [[wherever he goes]].

The same relative adverbs as in $(17 \mathrm{a} \& \mathrm{~b})$ occur also in relative sentences with an overt antecedent, examples of which were given in $(9 a \& b)$ above and are repeated as $(19 \mathrm{a} \& \mathrm{~b})$, respectively:

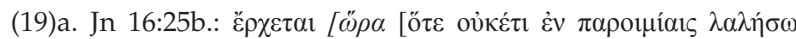
טนกัv]].

['a time is coming when I will no longer speak to you by means of figures of speech']

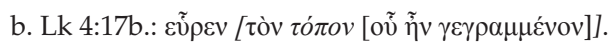

['he found the place where it was written']

Compare the examples by Lehmann (1984:318) from German given in $(20 a \& b)$ with those in $(19 a \& b)$, respectively:

\section{(20)a. Zeit, als es passiert ist \\ ['time when it happened'] \\ b. Ort, wo es passiert ist \\ ['place where it happened']}

Free relatives denoting time, cause and manner are sometimes introduced by fixed phrases containing relative pronouns and function also like adverbs. This includes temporal prepositional phrases (for example, $\dot{\alpha} \varphi$ ' $\tilde{\zeta}, \dot{\alpha} \varphi$ ' oṽ ['since'], ăxpıs oṽ ['until'], etc.), causal prepositional phrases (for example, $\alpha \dot{\alpha} \theta$ ' $\tilde{\omega} v$ ['because'], $\dot{\varepsilon} \varphi$ ' $\tilde{\varphi}$ ['because'], etc.) and fixed phrases denoting manner consisting of a noun and a relative pronoun (for example, ôv $\tau$ ○ó $\pi$ ov ['just) as']). Compare the following examples from Wallace (1996):

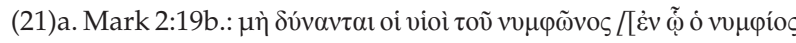

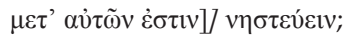

['the friends of the bridegroom cannot fast while the bridegroom is with them, can they?']

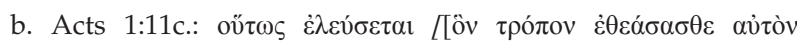

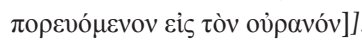

['he will come just as you saw him go to heaven']. (pp. 664-665) 
In (21a) the fixed temporal phrase $\dot{\varepsilon} v \tilde{\omega}$ ['while'] introduces the relative sentence, which denotes the temporal circumstances for $\delta v ́ v \alpha v \tau \alpha \iota . . v \eta \sigma \tau \varepsilon v ́ \varepsilon ı v$ ['can ... fast']. In (21b) the fixed phrase

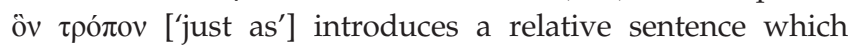
denotes manner with regard to $\dot{\varepsilon} \lambda \varepsilon v ́ \sigma \varepsilon \tau \alpha 1$ ['he will come'].

Traditional literature on the Greek NT, for example, Burton (1894:117-129), Dana and Mantey (1957:272), Schwyzer (1959:642) and Blass and Debrunner ([1913] 1967:191192, [1913] 1979:306-309) distinguish also 'conditional', 'causal', 'final', 'concessive' and 'resultative' uses of the relative sentence as part of its adverbial function. The same distinctions occur also in more recent grammars on NT Greek, for example, Hewett (1986:170-171), Wallace (1996:662-665), Young (1994:231-233), Stevens (1997:337), Porter (1992:247) and McKay (1994:124, 137, 144).

These so-called uses of the relative sentence are not discussed in any detail here, save to say that they are pseudo-adverbial, and that the examples given in the literature are all identifying or appositive relative sentences. The pseudo-adverbial uses are pragmatic distinctions on account of the content of certain relative sentences and main sentences and are not significant distinctions at the level of sentence grammar. For a detailed discussion, see Du Toit (1984:63-74, 1986:6-15).

\section{Continuative relative sentences}

It is argued by some scholars that relative sentences seem to function like a conjoined sentence in certain cases, and that this constitutes another function of the relative sentence. Compare the following example from Winer ([1855] 1882):

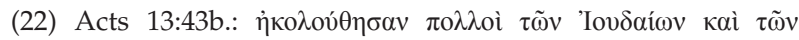

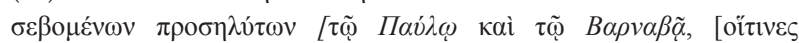

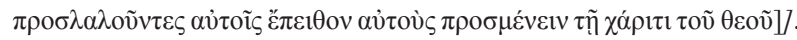

['many of the Jews and devout proselytes followed Paul and Barnabas, who spoke to them and kept urging them to continue in the grace of God']. (p. 479)

In (22), the relative sentence seems to be conjoined to the previous sentence and equivalent to 'and they spoke to them and kept urging them to continue in the grace of God.' The relative sentence in (22) could also be interpreted as an appositive relative providing background information for the

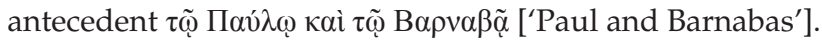

This use of the relative sentence has also parallels in English. Loetscher (1973:366) points out that (what he terms) 'nonrestrictive' relative sentences in sentence-final position have more focus and sometimes form part of a description. Compare his example given in (23):

(23) Did you get anything to eat yesterday evening? - Oh yes, Paul invited us to his [home, [where he offered us a splendid dinner]].

In this case, the relative sentence does not seem to provide background information, but rather to be part of the description and on the same level as 'Paul invited us to his home'.
According to Levinsohn (2000:191) such 'continuative' relative sentences typically describe an event that involves the referent of the relative pronoun and occurs subsequent to the previous event or situation in which the referent featured. Compare his example given in (24):

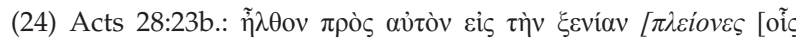

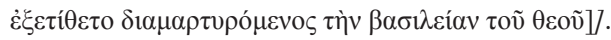

['many came to him in his guestroom/place where he was staying, and he testified and explained to them the kingdom of God']

However, it could also be argued that relative sentences like the ones in (22) and (24) are not relative sentences in the real sense of the word. For example, although they are introduced by forms of ö $\tau \imath \varsigma$ and ö $\varsigma$, which usually function as relative pronouns introducing relative sentences, they seem to have a rather loose connection to their referents, compared to identifying and appositive relative sentences. They seem also close to independent sentences introduced by ö $\sigma \tau \iota \varsigma$ and ö $\varsigma$. Lastly, the anaphoric relationship that obtains between ö $\sigma 1 \mathrm{~s}$ and ö $\varsigma$ and their referents could be regarded as the same as the relationship between a nominal expression in the first of two conjoined sentences and a coreferential demonstrative or personal pronoun in the second sentence. The issue clearly requires further research.

There is general agreement amongst linguists that coordination is a poorly understood and challenging phenomenon, and there is much debate in the literature on the syntax of coordinate constructions (J. Oosthuizen, pers. comm., 16 June 2014). For a detailed discussion of various issues relating to the syntax of coordination, compare Zhang (2010).

\section{Conclusion}

The view of the functions of the relative sentence in the Greek NT, as developed in the mid-1980s, still seems to be valid. This is supported to a large extent by more recent literature on the Greek NT in as far as the relative sentence's adjectival use is concerned, despite some differences relating to nuances and terminology. However, recent NT grammars still distinguish so-called 'conditional', 'concessive', 'causal', 'final' and 'resultative' relative sentences as part of the relative sentence's adverbial function, despite strong evidence to the contrary.

It seems, then, that relative sentences in the Greek NT have the following four functions, which correspond to those in numerous modern languages:

1. Identifying a referent(s) together with a nominal antecedent. This applies also in cases where relative sentences are introduced by relative adverbs. In the case of free relatives, the relative sentence identifies the referent on its own, without an overt antecedent (= the 'identifying' function).

2. Providing background or additional information for a nominal or sentential antecedent in the form of a parenthesis, explanation or concession, or some combination of these (= the 'appositive' function). 


\begin{tabular}{|c|c|c|c|}
\hline Identifying & Appositive & Adverbial & Continuative \\
\hline $\begin{array}{l}\text { Identification } \\
\text { of a referent } \\
\text { together with } \\
\text { or without an } \\
\text { antecedent }\end{array}$ & $\begin{array}{l}\text { Providing background or } \\
\text { additional information for } \\
\text { a nominal element or a } \\
\text { sentence as antecedent }\end{array}$ & $\begin{array}{l}\text { Qualifying a verb } \\
\text { with regard to time, } \\
\text { location or manner }\end{array}$ & $\begin{array}{l}\text { Functioning as a } \\
\text { conjoined sentence }\end{array}$ \\
\hline
\end{tabular}

FIGURE 1: Functions of the relative sentence in New Testament Greek.

3. Qualifying a verb with regard to time, location or manner, like an adverb (= the 'adverbial' function).

4. Functioning as a conjoined sentence (= the 'continuative' function), although the validity of this function is debatable.

The functions of the relative sentence in NT Greek could be represented as above in Figure 1.

\section{Acknowledgements Competing interests}

The author declares that he has no financial or personal relationships which may have inappropriately influenced him in writing this article.

\section{References}

Aronson, H.A., 1972, 'Some notes on relative clauses in Georgian', in P.M. Peranteau, J.N. Levi \& G.C. Phares (eds.), The Chicago which hunt: Papers from the relative clause festival, A paravolume to papers from the eighth regional meeting, pp. 136-143, Chicago Linguistic Society, Chicago, IL.

Blass, F. \& Debrunner, A., [1913] 1967, A Greek grammar of the New Testament and other early Christian literature, transl. \& rev. by R.W Funk, University of Chicago Press, Chicago, IL/The University of Toronto Press, Toronto.

Blass, F. \& Debrunner, A., [1913] 1979, Grammatik des neutestamentlichen Griechisch, 14. Aufl., völlig neubearbeitet und erweitert von F. Rehkopf, VandenHoeck, Göttingen.

Boyer, J.L., 1988, 'Relative clauses in the Greek New Testament: A statistical study', Grace Theological Journal 9(2), 233-256.

Burton, E. de W., 1894, Syntax of the moods and tenses in New Testament Greek, 2nd edn., T. \& T. Clark, Edinburgh.

Chomsky, N., 1977, Essays on form and interpretation, Mouton, The Hague.

Comrie, B., 1989, Language universals and linguistic typology, Syntax and morphology, 2nd edn., University of Chicago Press, Chicago, IL.

Dana, H.E., \& Mantey, J.R., 1957, A manual grammar of the Greek New Testament, Macmillan, Toronto.

Danker, F.W., 2000, A Greek-English lexicon of the New Testament and other early Christian literature, 3rd edn., University of Chicago Press, Chicago, IL.

De Rijk, R.P.G., 1972, 'Relative clauses in Basque: A guided tour', in P.M. Peranteau, J.N. Levi \& G.C. Phares (eds.), The Chicago which hunt: Papers from the relative clause festival, pp. 115-135, Chicago Linguistic Society, Chicago, IL.

De Vries, M., 2006, 'The syntax of appositive relativization: On specifying coordination, false free relatives, and promotion', Linguistic Inquiry 37(2), 229-270. http:// dx.doi.org/10.1162/ling.2006.37.2.229

Du Toit, H.C., 1984, 'Semantiek en sintaksis van relatiewe sinne in die Griekse Nuwe Testament', D.Litt. Dissertation, Dept. of Greek, University of Pretoria.

Du Toit, H.C., 1986, 'Semantics of relative sentences in Ancient Greek', South African Journal of Linguistics 4(1), 1-20. http://dx.doi.org/10.1080/10118063.1986.972 4413

Du Toit, H.C., 2014, 'The semantics and syntax of relative sentences in the Greek New Testament', paper presented at the 69th General Meeting of the Studiorum Novi Testamenti Societas (SNTS), Szeged, Hungary.

Ebert, K.H., 1973, 'Functions of relative clauses in reference acts', Linguistische Berichte 23, 1-11.

Ehrenkranz, J. \& Hirchland, C., 1972, 'Latin relative clauses', in P.M. Peranteau, J.N. Levi \& G.C. Phares (eds.), The Chicago which hunt: Papers from the relative clause festival, pp. 23-29, Chicago Linguistic Society, Chicago, IL.

Gilliard, F., 1989, 'The problem of the anti-semitic comma between 1 Thess. 2:14 and 15 ', New Testament Studies 35(4), 481-502. http://dx.doi.org/10.1017/ S0028688500015162
Gołạb, Z., 1972, 'The relative clause in Slavic. I. Common Slavic and North Slavic', in P.M. Peranteau, J.N. Levi \& G.C. Phares (eds.), The Chicago which hunt: Papers from the relative clause festival, pp. 30-39, Chicago Linguistic Society, Chicago, IL.

Hewett, J.A., 1986, New Testament Greek. A beginning and intermediate grammar, Hendrickson Publishers, Peabody, MA.

Karlsson, F., 1972, 'Relative clauses in Finnish', in P.M. Peranteau, J.N. Levi \& G.C. Phares (eds.), The Chicago which hunt: Papers from the relative clause festival, pp. 106-114, Chicago Linguistic Society, Chicago, IL.

Keenan, E.L., 1972, 'Relative clause formation in Malagasy', in P.M. Peranteau, J.N. Levi \& G.C. Phares (eds.), The Chicago which hunt: Papers from the relative clause festival, pp. 169-189, Chicago Linguistic Society, Chicago, IL.

Kilean, C.G., 1972, 'Arabic relative clauses', in P.M. Peranteau, J.N. Levi \& G.C. Phares (eds.), The Chicago which hunt: Papers from the relative clause festival, pp. 144-152, Chicago Linguistic Society, Chicago, IL.

Lehmann, C., 1984, Der Relativsatz: Typologie seiner Strukturen; Theorie seiner Funktionen; Kompendium seiner Grammatik, Gunter Narr Verlag, Tübingen. (Language Universal, ser. 3).

Levinsohn, S.H., 2000, Discourse features of New Testament Greek. A coursebook on the information structure of New Testament Greek, 2nd edn., Summer Institute of Linguistics, Dallas.

Loetscher, A., 1973, 'On the role of nonrestrictive relative clauses in discourse', in C. Corum, T.C. Smith-Stark \& A. Weiser (eds.), Papers from the ninth regional meeting, Chicago linguistic society, pp. 356-368, Chicago Linguistic Society, Chicago, IL.

McCawley, J.D., 1972, 'Japanese relative clauses', in P.M. Peranteau, J.N. Levi \& G.C. Phares (eds.), The Chicago which hunt: Papers from the relative clause festival, pp. 205-214, Chicago Linguistic Society, Chicago, IL.

McKay, K.L., 1994, A new syntax of the verb in New Testament Greek: An aspectual approach, in D.A. Carson (ed.), Peter Lang Publishing, New York. (Studies in Biblical Greek, 5).

Peranteau, P.M., Levi, J.N. \& Phares, G.C. (eds.), 1972, The Chicago which hunt: Papers from the relative clause festival, Chicago Linguistic Society, Chicago, IL.

Perlmutter, D.M., 1972, 'Evidence for shadow pronouns in French relativization', in P.M. Peranteau, J.N. Levi \& G.C. Phares (eds.), The Chicago which hunt: Papers from the relative clause festival, pp. 73-105, Chicago Linguistic Society, Chicago, IL.

Porter, S.E., 1992, Idioms of the Greek New Testament, JSOT Press, Sheffield.

Porter, S.E., 2013, 'Translation, exegesis, and 1 Thessalonians 2.14-15. Could a comma have changed the course of history?', The Bible Translator 64(1), 82-98. http:// dx.doi.org/10.1177/0260093513481150

Quirk, R., Greenbaum, S., Leech, G. \& Svartvik, J., 1985, A comprehensive grammar of the English language, Longman, New York, NY.

Radford, A., 2009, Analysing English sentences: A minimalist approach, Cambridge University Press, New York, NY. http://dx.doi.org/10.1017/СBO9780511 801617

Robertson, A.T., 1919, A grammar of the Greek New Testament in the light of historical research, 3rd rev. edn., Cambridge University Press, Cambridge.

Schwyzer, E., 1959, Griechische Grammatik. Auf der Grundlage von Karl Brugmanns Griechischer Grammatik, 2. Bd., Syntax und syntaktische Stilistik, vervollständigt u. herausgegeben von A. Debrunner (ed.), 2. Aufl., C.H. Beck'sche Verlagsbuchhandlung, München. (Handbuch der Altertumswissenschaft, 2/1).

Smith, C.S., 1964, 'Determiners and relative clauses in a generative grammar of English', in D.A. Reibel \& S.A. Shane (eds.), Modern studies in English: Readings in transformational grammar, pp. 247-263, Prentice Hall, Englewood Cliffs, NJ.

Smyth, H.W., 1976, Greek grammar, Harvard University Press, Cambridge.

Stevens, G.L., 1997, New Testament Greek, 2nd edn., University Press of America, Lanham, MD.

Tagashira, Y., 1972, 'Relative clauses in Korean', in P.M. Peranteau, J.N. Levi \& G.C. Phares (eds.), The Chicago which hunt: Papers from the relative clause festival, pp. 215-229, Chicago Linguistic Society, Chicago, IL.

Voelz, J.W., 2006, 'Participles, Pt. 3', Concordia Journal, October, 401-403.

Wallace, D.B., 1996, Greek grammar beyond the basics: An exegetical syntax of the New Testament, Zondervan Publishing House, Grand Rapids, MI.

Winer, G.B. [1855] 1882, A treatise on the grammar of New Testament Greek, 3rd rev. edn., transl. W.F. Moulton, T. \& T. Clark, Edinburgh.

Young, R.A., 1994, Intermediate New Testament Greek: A linguistic and exegetical approach, Broadman \& Holman Publishers, Nashville, TN.

Zhang, N.N., 2010, Coordination in syntax, Cambridge University Press, Cambridge. (Cambridge Studies in Linguistics). 